Article

\title{
Active Learning: Subtypes, Intra-Exam Comparison, and Student Survey in an Undergraduate Biology Course
}

\author{
Kristen M. McGreevy ${ }^{1,2}$ and Frank C. Church ${ }^{3, *}$ \\ 1 Departments of Biostatistics and Biology, University of North Carolina at Chapel Hill, \\ Chapel Hill, NC 27599, USA; kristenmae@g.ucla.edu \\ 2 Department of Biostatistics, University of California, Los Angeles, CA 90095, USA \\ 3 Department of Pathology and Laboratory Medicine, University of North Carolina School of Medicine, \\ Chapel Hill, NC 27599, USA \\ * Correspondence: fchurch@med.unc.edu
}

Received: 15 May 2020; Accepted: 14 July 2020; Published: 20 July 2020

\begin{abstract}
Active learning improves undergraduate STEM course comprehension; however, student comprehension using different active learning methods and student perception of active learning have not been fully explored. We analyze ten semesters (six years) of an undergraduate biology course (honors and non-honors sections) to understand student comprehension and student satisfaction using a variety of active learning methods. First, we describe and introduce active learning subtypes. Second, we explore the efficacy of active learning subtypes. Third, we compare student comprehension between course material taught with active learning or lecturing within a course. Finally, we determine student satisfaction with active learning using a survey. We divide active learning into five subtypes based on established learning taxonomies and student engagement. We explore subtype comprehension efficacy (median \% correct) compared to lecture learning (median $92 \%$ correct): Recognition (100\%), Reflective (100\%), Exchanging (94.1\%), Constructive (93.8\%), and Analytical (93.3\%). A bivariate random intercept model adjusted by honors shows improved exam performance in subsequent exams and better course material comprehension when taught using active learning compared to lecture learning ( $2.2 \%$ versus $1.2 \%)$. The student survey reveals a positive trend over six years of teaching in the Perceived Individual Utility component of active learning ( $\operatorname{tau}=0.21, p=0.014)$, but not for the other components (General Theoretical Utility, and Team Situation). We apply our findings to the COVID-19 pandemic and suggest active learning adaptations for newly modified online courses. Overall, our results suggest active learning subtypes may be useful for differentiating student comprehension, provide additional evidence that active learning is more beneficial to student comprehension, and show that student perceptions of active learning are positively changing.
\end{abstract}

Keywords: active learning subtypes; team-based skills; student active learning survey; undergraduate (target learners); biology; STEM; student engagement; innovations in education; COVID-19

\section{Introduction}

Active learning is a teaching method that engages students with subject material to enhance the learning experience compared to traditional lecturing styles [1-13]. Active learning has been linked to improving exam scores, increasing long-term material retention, and boosting learning experience [1-17]. In 1991, Bonwell and Eison [5] originally defined active learning as, "anything that involves students doing things and thinking about the things they are doing". More recently, in 2015, the National Survey of Student Engagement and the Australasian Survey of Student Engagement simply stated that active learning involves "students' efforts to actively construct their 
knowledge." (from [18]). Active learning requires engaging the student learner with the course content; however, in many higher education classes, the more traditional (and passive student engagement) lecture typically prevails [19]. Newer studies and reviews have been bolstering active learning in STEM and health care higher education settings. Some of these include the use of innovative pedagogical practices [20], the effectiveness of the flipped-classroom to the traditional classroom [21], implementing inclusion, diversity, and equity in active learning [22], and assessing student beliefs in education by active learning [23].

Research has shown students generally learn better with diverse teaching methods [24]; however, the efficacy (evaluated using student comprehension) of specific teaching methods are not well understood. This gap in research motivated us to understand the subtypes of active learning methods and evaluate student performance in each. Active learning research has typically compared student comprehension across courses $[18,25]$. In these comparisons, the amount of active learning integration and the type of active learning are often unobserved. However, our interest is to compare subject comprehension between the material taught with active learning methods and with traditional lecture learning methods within a single course. In our study setting, we control for differences in instructors and differences in the student composition, as the same instructor has taught the course in all years and comprehension differences are evaluated within individual students, instead of across entire course platforms. Furthermore, research has shown students learn better from active learning than lecture learning [1-17]; however, students are still convinced they learn more from a traditional lecture than from an active learning experience [25]. The dissonance in student perception of learning and research on student learning motivated us to understand if students' perceptions of active learning are changing over-time.

We analyzed ten semesters across six years of an upper-level undergraduate biology course taught with partial active learning components at UNC-Chapel Hill titled "Biology of Blood Diseases". Our research revolved around the following objectives: (i) describe active learning subtypes; (ii) explore the efficacy (via student performance) of different active learning subtypes; (iii) compare student comprehension within a course between course material taught with active learning or lecture learning; and (iv) determine student satisfaction on this course with active learning methods. From these four tasks, we sought to answer three questions related to active learning. First, does student course comprehension vary based on the subtype of active learning used? Second, is student comprehension better on the course topics taught through active learning or lecture learning? Third, how do students perceive active learning and are students becoming more accepting of active learning methods?

\section{Materials and Methods}

\subsection{Course Information}

F.C.C. has been the sole lecturer in the undergraduate biology course used in this study since 1996. The students are mainly seniors $(>95 \%)$ with a focus in health-related careers (Medicine, Dentistry, Physician Assistant, Nursing, Pharmacy, Occupational Therapy, Public Health, and graduate school in life/health sciences), and they have passed core biology courses. The majority of the students enrolled in this course are majoring in Biology, Psychology, Nutrition, Exercise and Sport Science, Epidemiology, or Anthropology. The course has four units and teaches 34 topics covering the biological mechanism and progression of blood and blood-forming organ diseases from a medical and pathological perspective, 13 of which are taught with pre-specified active learning activities (Table 1). The present study analyzes the active learning components from 2012 to 2018. The course was taught in honors (which enrolls $\sim 25$ students) and non-honors sections (which enrolls 60-80 students). The primary difference between honors and non-honors sections is the honors section class write and present more during the semester; however, lecture content and exam material are essentially equivalent. 
Table 1. Description of active learning activities.

\begin{tabular}{|c|c|c|}
\hline Activity & Description & Subtype Category \\
\hline Flipped classroom lecture(s) & $\begin{array}{l}\text { Pre-recorded videos (pptx and } \mathrm{mp} 4 \text { files with voice-over) that students watch } \\
\text { outside of the classroom on their own. These at-home videos were paired } \\
\text { with an on-line recall quiz, which was always due prior to the start of class. }\end{array}$ & Recognition \\
\hline Journal Article & $\begin{array}{l}\text { Peer-reviewed articles students independently read outside of class and they } \\
\text { are related to lecture topic (guidelines given on what to read/appreciate); } \\
\text { questions regarding the reading were included in an on-line quiz due by } \\
\text { class time. }\end{array}$ & Recognition \\
\hline Ethical Dilemmas & Class-wide discussion about ambiguous medical scenarios presented by FCC. & Exchanging \\
\hline Student Thought Notecards & $\begin{array}{l}\text { Students' anonymous, individual responses to in-class questions that are } \\
\text { exchanged with others to read and discuss in class. }\end{array}$ & Exchanging \\
\hline Thought-filled Responses & $\begin{array}{l}\text { Short online posts or in-class responses students write that are not directly } \\
\text { related to course material. As an example, students would read a descriptive } \\
\text { essay of a physician caring for a terminal cancer patient and they would then } \\
\text { reflect and respond to any aspect of the storyline. }\end{array}$ & Reflective \\
\hline $\begin{array}{l}\text { Computer-based Corners, } \\
\text { Kahoot! Plickers, } \\
\text { and Jeopardy }\end{array}$ & $\begin{array}{l}\text { Team-based question games where each group has limited time to read and } \\
\text { answer a question. In Corners, the team gives their answer on a class forum } \\
\text { in Sakai. In Kahoot! the team uses the internet to respond. In Plickers, } \\
\text { a cell-phone reads and reveals the team's anonymous answer. In Jeopardy, } \\
\text { the team responds with laminated placards and they kept their own score. }\end{array}$ & Constructive \\
\hline Basic Science Workshops & $\begin{array}{l}\text { A series of questions (multiple choice and short answer) that address the } \\
\text { chemical or scientific components of the class material and usually ending by } \\
\text { including some medical application. }\end{array}$ & Analytical \\
\hline Clinical Case Studies & $\begin{array}{l}\text { Worksheets with medical scenarios and the group will be asked to diagnose } \\
\text { the patient, order the necessary tests, recommend proper therapy, or describe } \\
\text { the biological origin and expected disease progression. Students are } \\
\text { encouraged to research online to help find the answers. }\end{array}$ & Analytical \\
\hline Role Play & $\begin{array}{l}\text { Each member in the group acts according to a pre-assigned medical role } \\
\text { (i.e., a patient, spouse/partner, nurse, medical student, doctor, specialist). } \\
\text { As each person is queued, information is gathered and students order the } \\
\text { necessary tests, recommend proper therapy, make diagnosis, or describe the } \\
\text { biological origin and expected disease progression. Students are encouraged } \\
\text { to research online to help find the answers and complete a limited } \\
\text { History \& Physical Report. }\end{array}$ & Analytical \\
\hline
\end{tabular}

Instructor integration and understanding of active learning in their course varies [2]. Active learning is usually perceived as a dichotomous force in the classroom-either a professor teaches with it or not; however, an entire course may incorporate only some of the course material through active learning methods $[7,26,27]$. We reason that, if part of your teaching involves active learning and may vary from other instructors, we should develop an active learning statement grounded on your own teaching experiences. For the basis of our study, (i) we define active learning as an interactive teaching method that calls upon students to discover the subject material through student-based activities. (ii) Active learning requires the expression of ideas and opinions in small groups that ultimately blend into an entire class discussion; thus, it ignites students' innate curiosity. (iii) Active learning activities strengthen team-based skills of collaboration, conversation, cooperation, and collegiality. (iv) Active learning engages all types of students with each other and the instructor, promoting the disintegration of racial, socioeconomic, and intelligence boundaries.

In addition to F.C.C.'s active learning, his personal interaction heightened many aspects of the classroom. First, he organized 4-5 class events a semester, including dinners, lunches, and potlucks. Second, F.C.C. established trust with his students by sharing his vulnerabilities, such as his life in the presence of Parkinson's disease and his blog, ("Journey with Parkinson's") [28]. By engaging students in a non-academic environment and sharing a personal life health event, he was attempting to strengthen inter-student relationships with the hope of improving overall classroom engagement for the students.

This research was conducted under the guidelines of UNC IRB Study 19-02137. 


\subsection{Exam Information}

Exams were a combination of multiple choice (A-E), matching, true-false, and free-response questions and were given three times a semester varying in length from 47 questions to 64 . Only the multiple choice, matching, and true-false response sections for each exam were used in the analyses. Each semester exam covered the same course material as the previous year, maintaining exam continuity; however, the same exam questions were not used in subsequent semesters. Exams were scored using the University Scantron system.

\subsection{Exam Question Categorization}

First, all exam questions were marked corresponding to the topic they were testing and the course lesson the question originated from. Second, each exam (33 in total) from 2012 to 2018 was reviewed to designate each question as taught through active learning or lecture learning (Table 2). Third, each exam (separately from above) was reviewed question-by-question to designate each active learning subtype. All coding was performed in SAS University Edition 9.4 by K.M.M. The SAS code is available as macros, which can be modified to another dataset in the same format.

Table 2. Overview of course sections and exam information.

\begin{tabular}{|c|c|c|c|c|c|c|c|c|c|c|}
\hline \multirow{2}{*}{ Semester } & \multirow{2}{*}{ Section } & \multirow{2}{*}{$\begin{array}{l}\text { Students } \\
\text { Included }\end{array}$} & \multirow{2}{*}{ Exam } & \multicolumn{5}{|c|}{ Active Learning Questions by Subtypes } & \multirow{2}{*}{$\begin{array}{c}\text { Active Learning } \\
\text { Questions }\end{array}$} & \multirow{2}{*}{$\begin{array}{l}\text { Total Exam } \\
\text { Questions }\end{array}$} \\
\hline & & & & $\mathbf{R}$ & $\mathrm{E}$ & $\mathrm{C}$ & $\mathbf{F}$ & A & & \\
\hline \multirow{3}{*}{ Fall 2012} & \multirow{3}{*}{ Not Honors } & \multirow{3}{*}{71} & 1 & 5 & 0 & 8 & 0 & 6 & 19 & 56 \\
\hline & & & 2 & 2 & 0 & 26 & 0 & 5 & 33 & 60 \\
\hline & & & 3 & 7 & 11 & 0 & 6 & 9 & 33 & 52 \\
\hline \multirow{3}{*}{ Fall 2013} & \multirow{3}{*}{ Not Honors } & \multirow{3}{*}{78} & 1 & 6 & 0 & 10 & 0 & 7 & 23 & 55 \\
\hline & & & 2 & 2 & 0 & 17 & 0 & 7 & 26 & 55 \\
\hline & & & 3 & 3 & 12 & 0 & 5 & 15 & 35 & 64 \\
\hline \multirow{3}{*}{ Fall 2014} & \multirow{3}{*}{ Honors } & \multirow{3}{*}{25} & 1 & 9 & 0 & 10 & 0 & 6 & 25 & 52 \\
\hline & & & 2 & 2 & 0 & 21 & 0 & 2 & 25 & 50 \\
\hline & & & 3 & 3 & 14 & 0 & 2 & 14 & 33 & 57 \\
\hline \multirow{3}{*}{ Spring 2015} & \multirow{3}{*}{ Not Honors } & \multirow{3}{*}{60} & 1 & 9 & 0 & 8 & 0 & 6 & 23 & 52 \\
\hline & & & 2 & 3 & 0 & 16 & 0 & 7 & 26 & 55 \\
\hline & & & 3 & 2 & 17 & 0 & 0 & 11 & 30 & 59 \\
\hline \multirow{3}{*}{ Fall 2015} & \multirow{3}{*}{ Honors } & \multirow{3}{*}{22} & 1 & 9 & 0 & 10 & 0 & 6 & 25 & 50 \\
\hline & & & 2 & 0 & 0 & 22 & 0 & 4 & 26 & 52 \\
\hline & & & 3 & 1 & 13 & 0 & 1 & 15 & 30 & 57 \\
\hline \multirow{3}{*}{ Spring 2016} & \multirow{3}{*}{ Not Honors } & \multirow{3}{*}{60} & 1 & 10 & 0 & 7 & 0 & 5 & 22 & 47 \\
\hline & & & 2 & 2 & 0 & 15 & 0 & 8 & 25 & 50 \\
\hline & & & 3 & 2 & 17 & 0 & 0 & 13 & 32 & 64 \\
\hline \multirow{3}{*}{ Fall 2016} & \multirow{3}{*}{ Honors } & \multirow{3}{*}{19} & 1 & 12 & 0 & 10 & 0 & 7 & 29 & 53 \\
\hline & & & 2 & 0 & 0 & 22 & 0 & 4 & 26 & 52 \\
\hline & & & 3 & 1 & 13 & 0 & 1 & 15 & 30 & 57 \\
\hline & & & 1 & 9 & 0 & 7 & 0 & 5 & 21 & 47 \\
\hline Spring 2017 & Not Honors & 59 & 2 & 2 & 0 & 16 & 0 & 7 & 25 & 50 \\
\hline & & & 3 & 2 & 17 & 0 & 0 & 13 & 32 & 64 \\
\hline & & & 1 & 11 & 0 & 10 & 0 & 7 & 28 & 53 \\
\hline Fall 2017 & Honors & 25 & 2 & 2 & 0 & 15 & 0 & 7 & 24 & 54 \\
\hline & & & 3 & 2 & 18 & 0 & 0 & 12 & 32 & 64 \\
\hline & & & 1 & 10 & 0 & 8 & 0 & 5 & 23 & 52 \\
\hline Spring 2018 & Not Honors & 57 & 2 & 2 & 0 & 15 & 0 & 7 & 24 & 54 \\
\hline & & & 3 & 2 & 17 & 0 & 0 & 13 & 32 & 64 \\
\hline
\end{tabular}

Note: The total questions are out of the exam questions included in the analysis; free response questions are not counted in this total. $\mathrm{R}=$ Recognition, $\mathrm{E}=$ Exchanging, $\mathrm{C}=$ Constructive, $\mathrm{F}=$ Reflective, $\mathrm{A}=$ Analytical.

\subsection{Defining and Describing Active Learning Subtypes}

To define active learning subtypes, we researched and mirrored the methodology of learning. Each teaching approach used in active learning is categorized into a subtype, and the subtypes reflect Bloom's Taxonomy of Learning [29-33]. The taxonomy establishes a hierarchical aspect to learning, which we integrated into the active learning subtypes. Other research, like the Interactive, Constructive, 
Active, and Passive, or ICAP framework from 2014, has developed progressive levels of learning, but includes passive learning, i.e., non-active learning components as part of the framework [34]. Defining subtypes for levels of active learning is an attempt to both mimic and complement the traditional hierarchical structure of learning levels found in Bloom's Revised Taxonomy of Learning [29-33].

\subsection{Active Learning Subtype Analysis}

The proportion correct by each active learning subtype (Analytical, Constructive, Exchanging, Recognition, or Reflective) was scored for each student and exam. A Kruskal-Wallis rank test [35] was performed to detect an overall difference in the proportion correct among active learning subtypes. We chose a non-parametric rank test because scores were ordered and score distributions appeared to be non-normal and skewed. Following a significant result, a Dwass-Steel-Critchlow-Fligner test [36] was applied to make nonparametric, two-sided, pairwise comparisons between all subtypes. This test was chosen because it controls family-wise error when performing multiple comparisons.

\subsection{Intra-Exam Analysis}

We use a bivariate random intercept model to analyze student comprehension in course material taught through active learning or lecture learning. This multilevel model is appropriate for longitudinal data and/or repeated measures. Furthermore, because we are interested in two outcomes simultaneously-active learning comprehension and lecture learning comprehension-this method allows a flexible correlation structure among the two outcomes (instead of assuming independence). The proportion correct on active learning and lecture learning questions for each student (for each exam) were used as the two outcomes of interest. Our data have dependency (1) between lecture learning and active learning comprehension within any student and (2) among exams $1-3$. The random effects and error terms are allowed to be correlated, time was defined using exam number, and we controlled for honors. Random effects include student-specific random intercepts and unstructured covariance matrices were used. All ten courses were combined with 1428 total observations (three exams per student).

\subsection{Survey Description}

In 2012, we adapted a previously developed student survey on team-based learning to gain student feedback on active learning in the course [37]. The active learning survey was voluntary, anonymous, electronic, and consisted of 15 statements and an open-ended comment section. It was sent to the students at the end of the semester of both honors and non-honors sections. Students were asked to rate the extent to which they agreed or disagreed about active learning integration on a 1-5 Likert scale (1 strongly disagree, 5 strongly agree). We placed the 15 survey statements onto three distinct components: Perceived Individual Utility (7 statements), General Theoretical Utility (4 statements), and Team Situation (4 statements).

\subsection{Survey Analysis}

To determine the overall satisfaction of the students with the different components of Active Learning in the classroom, the median response score was calculated for each of the three survey components for each semester: Perceived Individual Utility, General Theoretical Utility, and Team Situation. Statement 3 was reverse scored to be in favor of active learning. The non-parametric Mann-Kendall trend test [38] was used to detect if a significant monotonic time trend across the three surveyed components existed: Perceived Individual Utility, General Theoretical Utility, and Team Situation. We could condense the six years' data and observe summary statistics for each survey component to understand student perception; however, we chose to evaluate student perception of active learning dependent on time. If the actual data are independent and identically distributed, then each year we expect similar scores on the survey. Alternatively, if the actual data are independent and follow a monotonic trend, then each year we expect the scores to change generally in 
one-direction-either increasing or decreasing. This test was unadjusted for honors because of the limited data and power. To control the family-wise error rate, the $p$-value threshold was adjusted using the Holm-Bonferroni procedure [39]; the statistical significance threshold for the first comparison was at 0.017 , for the second at 0.025 , and for the third at 0.050 .

\section{Results}

\subsection{Active Learning Subtypes}

We divided active learning into five subtypes, similar to the hierarchical components in Bloom's Revised Taxonomy on Learning: Recognition, Exchanging, Reflective, Constructive, and Analytical. These subtypes are presented from least to most advanced level of interaction, respectively. Three types of knowledge govern the foundation for these active learning subtypes; namely, Technical Understanding (the knowledge of terminology, facts, and recall) includes the Recognition subtype. Theoretical Understanding (the knowledge of reasoning and feelings) incorporates the Exchanging and Reflective subtypes. Systematic Understanding (the knowledge of applying principles to synthesize answers and to diagnose problems) contains both Constructive and Analytical subtypes (Figure 1):

\begin{tabular}{|c|c|c|c|c|}
\hline $\begin{array}{c}\text { TECHNICAL } \\
\text { UNDERSTANDING }\end{array}$ & \multicolumn{2}{|c|}{$\begin{array}{l}\text { THEORETICAL } \\
\text { UNDERSTANDING }\end{array}$} & \multicolumn{2}{|c|}{$\begin{array}{c}\text { SYSTEMATIC } \\
\text { UNDERSTANDING }\end{array}$} \\
\hline $\begin{array}{l}\text { RECOGNITION } \\
\text { Flipped } \\
\text { Classroom } \\
\text { Lectures and } \\
\text { Journal } \\
\text { Articles }\end{array}$ & $\begin{array}{l}\text { EXCHANGING } \\
\text { Ethical } \\
\text { Dilemmas } \\
\text { and Student } \\
\text { Thought } \\
\text { Notecards }\end{array}$ & $\begin{array}{l}\text { REFLECTIVE } \\
\text { Thought-filled } \\
\text { Responses }\end{array}$ & $\begin{array}{l}\text { CONSTRUCTIVE } \\
\text { Team-based } \\
\text { games Corners, } \\
\text { Kahoot!,Plickers } \\
\text { Quizizz, and } \\
\text { Medical } \\
\text { Jeopardy }\end{array}$ & $\begin{array}{l}\text { ANALYTICAL } \\
\text { Basic Science } \\
\text { Workshops, } \\
\text { Clinical Case } \\
\text { Studies and } \\
\text { Medical Role } \\
\text { Play }\end{array}$ \\
\hline $\begin{array}{l}\text { Descriptive Terms: } \\
\text { Refine-Define, } \\
\text { Classify, Describe, } \\
\text { and Outline }\end{array}$ & $\begin{array}{l}\text { Descriptive Terms: } \\
\text { Analyze, Diagram, } \\
\text { Explain, and } \\
\text { Summarize }\end{array}$ & $\begin{array}{l}\text { Descriptive Terms: } \\
\text { Gather, Tell, } \\
\text { Discuss, Relate, } \\
\text { and Report }\end{array}$ & $\begin{array}{l}\text { Descriptive Terms: } \\
\text { Compare-Contrast, } \\
\text { Evaluate, Plan, and } \\
\text { Synthesize }\end{array}$ & $\begin{array}{l}\text { Descriptive Terms: } \\
\text { Create, Imagine, } \\
\text { Test a Hypothesis, } \\
\text { and Diagnosis }\end{array}$ \\
\hline
\end{tabular}

Figure 1. An overview of active learning subtypes with their associated learning taxonomy. The types of classroom experience(s) that best represent each of the subtypes and descriptive terms for each active learning subtype are included.

Recognition is the least interactive and is defined by independent student thinking with minimal communication/discussion with other students. Typically, this subtype requires student initiation and commitment to learning.

Exchanging requires students to independently consider the subject material in a similar application, communicate their thoughts, and discuss and listen to other students' ideas to complete their conceptualization.

Reflective combines an academic and personal component by evoking an emotional response or emphasizing student inclusion. It challenges students to consider their level of subject comprehension and deepens their feeling of importance in the classroom.

Constructive requires the discussion and comparison of course material with other students to arrive at an answer. Students are collaborating, recalling and applying the material, learning from each other, asking questions, and refining their understanding of subject material.

Analytical is the most advanced level of active learning that requires deep critical thinking; application of knowledge to the new subject material, research, and extensive group discussion/collaboration. Teaching others, while not employed in this course, also falls into this subtype. This subtype can be defined by student discovery and tends to consume the most time. 


\subsection{Active Learning Subtype Evaluation Results}

A priori subtyping active learning (described in detail above) allowed us to explore if different subtypes have varying efficacy in student comprehension. A Kruskal-Wallis (or Wilcoxon) test $[35,40]$ was performed to detect if an overall difference in student comprehension among the five active learning subtypes exists. The results strongly suggested at least one subtype differs in comprehension $(p<0.0001)$. To detect which subtype(s) they were, this analysis was followed by pairwise comparisons using the Dwass-Steel-Critchlow-Fligner Test [36]. Of the ten-paired comparisons between subtypes, eight of them were significant, even after adjusting the critical value for multiple comparisons (Table 3, Figure 2). This provides strong evidence to believe the active learning subtypes used in the course vary in comprehension efficacy. Specifically, our results show Recognition and Reflective active learning subtypes have better comprehension (both with a median 100\% correct) than Exchanging (94.1\%), which is better than Constructive (93.8\%), which is better than Analytical (93.3\%). For comparison, overall lecture learning had a mean of $89.3 \%$ and a median of $92 \%$ correct.

Table 3. Exam percent correct compared by active learning subtype.

\begin{tabular}{|c|c|c|c|c|c|}
\hline \multicolumn{6}{|c|}{ Nonparametric Overall Comparison } \\
\hline Subtype & $\mathbf{N}$ & Median & Mean & Kruskal-Wallis $\mathbf{H}$ & $p$-Value \\
\hline Recognition & 1383 & $100.0 \%$ & $87.6 \%$ & & \\
\hline Exchanging & 472 & $94.1 \%$ & $93.8 \%$ & & \\
\hline Reflective & 211 & $100.0 \%$ & $86.2 \%$ & 39.57 & $<0.0001$ \\
\hline Constructive & 952 & $93.8 \%$ & $91.8 \%$ & & \\
\hline Analytical & 1424 & $93.3 \%$ & $88.7 \%$ & & \\
\hline \multicolumn{6}{|c|}{ Nonparametric Pairwise Comparisons } \\
\hline \multicolumn{2}{|c|}{ Subtype Comparison } & Wilcoxon Z & DSCF Value & $p$-Value & Interpretation \\
\hline \multicolumn{2}{|c|}{ Constructive vs. Recognition } & -3.13 & 4.42 & 0.015 & $\mathrm{R}>\mathrm{C}$ \\
\hline \multicolumn{2}{|c|}{ Constructive vs. Analytical } & 2.80 & 3.96 & 0.041 & $C>A$ \\
\hline \multicolumn{2}{|c|}{ Constructive vs. Reflective } & -3.78 & 5.34 & 0.002 & $\mathrm{~F}>\mathrm{C}$ \\
\hline \multicolumn{2}{|c|}{ Constructive vs. Exchanging } & -2.96 & 4.18 & 0.026 & $\mathrm{E}>\mathrm{C}$ \\
\hline \multicolumn{2}{|c|}{ Recognition vs. Analytical } & 4.15 & 5.86 & $<0.001$ & $\mathrm{~F}>\mathrm{A}$ \\
\hline \multicolumn{2}{|c|}{ Recognition vs. Reflective } & -1.44 & 2.04 & 0.599 & uncertain \\
\hline \multicolumn{2}{|c|}{ Recognition vs. Exchanging } & 1.54 & 2.18 & 0.538 & uncertain \\
\hline \multicolumn{2}{|c|}{ Analytical vs. Reflective } & -3.60 & 5.09 & 0.003 & $\mathrm{~F}>\mathrm{A}$ \\
\hline \multicolumn{2}{|c|}{ Analytical vs. Exchanging } & -4.30 & 6.09 & $<0.001$ & $\mathrm{E}>\mathrm{A}$ \\
\hline \multicolumn{2}{|c|}{ Reflective vs. Exchanging } & 3.39 & 4.80 & 0.006 & $\mathrm{~F}>\mathrm{E}$ \\
\hline
\end{tabular}

$\mathrm{R}=$ Recognition, $\mathrm{E}=$ Exchanging, $\mathrm{C}=$ Constructive, $\mathrm{F}=$ Reflective, $\mathrm{A}=$ Analytical.

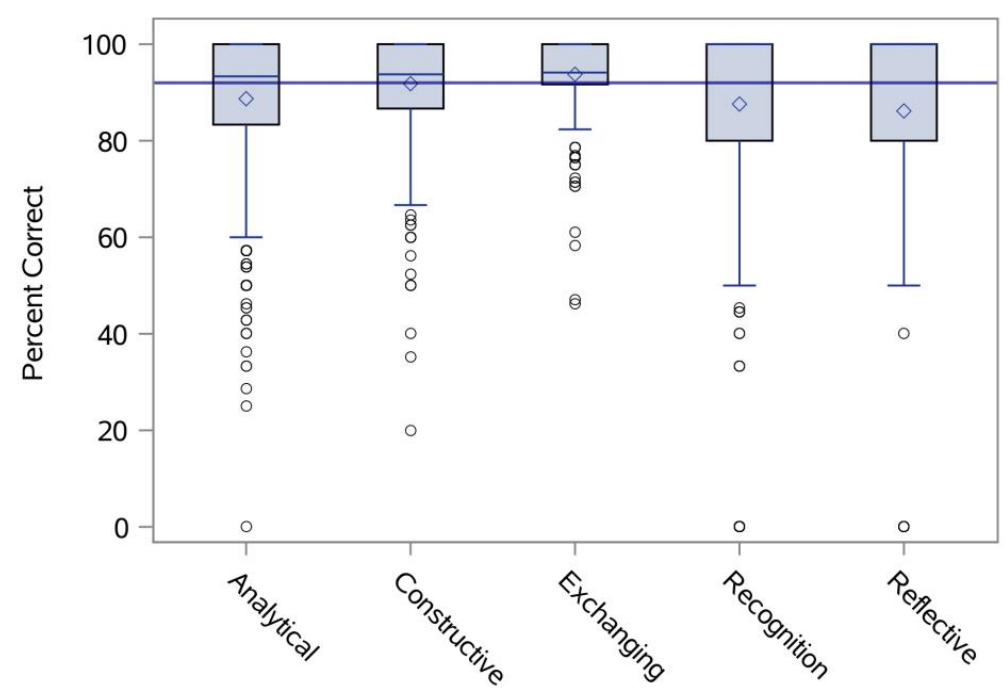

Figure 2. Proportion correct across active learning subtypes. The percentage of questions correct is plotted for each active learning subtype. Medians for the best subtypes, Recognition and Reflective, are at $100 \%$. The median proportion correct for lecture learning is displayed as a reference line (blue). 


\subsection{Intra-Exam Analysis Results}

The bivariate random intercept model showed slightly improved comprehension on course material taught with active learning compared to lecture learning within a course. Compared to the previous exam, students would score an average $2.2 \%$ higher on the active learning component and only $1.2 \%$ higher on the lecture learning component. This corresponds to a mean difference of $1.1 \%$ [confidence interval (CI) of $0.66-1.57 \%$ ] on active learning course components for future exams. Interestingly, students are expected to do marginally worse on the first exam's active learning component than in the lecture learning component. The covariance between active learning and lecture learning random intercepts is positive and estimated to be 29.3 (2.3 SE) (Table 4). Therefore, the average levels of the two exam scores are correlated. We were unable to detect a difference by honors course sections; the total number of honors students analyzed only totaled 91 , whereas the non-honors sections had a total of 385 students. The improvement in non-honors sections is relatively small and detailed in the Discussion. The inference plot displays the average comprehension improvement in exams (Figure 3).

Table 4. Intra-exam active learning to lecture learning comparison results.

\begin{tabular}{ccccc}
\hline & Estimate & Standard Error & T Statistic & $p$-Value \\
\hline Active Learning & \multicolumn{5}{c}{} \\
\hline Intercept & 85.8 & 0.76 & 112.2 & $<0.0001$ \\
Exam & 2.28 & 0.23 & 10.1 & $<0.0001$ \\
Honors & 0.65 & 0.68 & -1.0 & 0.34 \\
\hline Lecture Learning & \multicolumn{5}{c}{} \\
\hline Intercept & 87.5 & 0.78 & 112.7 & $<0.0001$ \\
Exam & 1.17 & 0.23 & 5.2 & $<0.0001$ \\
Honors & 0.65 & 0.68 & -1.0 & 0.34 \\
\hline \multicolumn{7}{c}{ Covariance Estimates } \\
\hline Active Learning & Active Learning & Lecture Learning & & \\
Lecture Learning & 20.3 & 29.3 & & \\
Residual Error & 29.3 & 27.6 & & \\
\hline
\end{tabular}
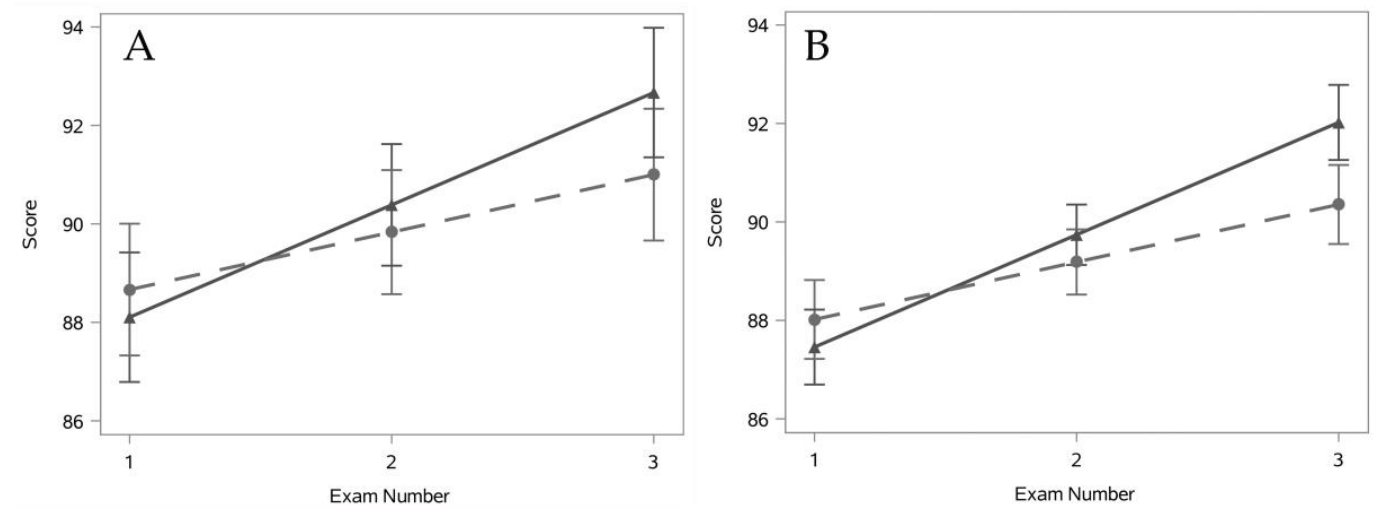

Figure 3. Estimated active learning and lecture learning scores separated by honors. The inference plot shows students' mean score between exam questions taught through active learning (solid line, triangles) and lecture learning (dashed line, circles) between the honors sections (A) and non-honors sections (B). The improvement is $1.1 \%$ better for active learning compared to lecture learning in previous exams [0.66\% to $1.57 \%]$.

\subsection{Active Learning Survey Results}

The survey responses were skewed towards favoring active learning and the course structure for almost all survey statements (Tables 5 and 6). Contrary to the mostly positive reaction to active 
learning, student responses from survey statement three show most students think they learn better by lectures than active learning regardless of year or honors, which confirms previous research [25]. Students perceived active learning as individually useful for them in the course; median scores range from 4.06-4.43 for Perceived Individual Utility, meaning students agree to strongly agree that active learning helped them learn the material in the course. Students perceived active learning as generally useful for classroom settings; median scores range from 4.40-4.80 for General Theoretical Utility, meaning students tend to strongly agree active learning helps the learning process in courses. A finding of the survey was the perception of quality teamwork during their active learning experience; median scores range from 4.62-4.85 for Team Situation, meaning students tend to strongly agree their team worked well in active learning activities. The open-ended portion of the survey shows students' favorite course activities included the Clinical Case Studies (Analytical subtype), Role Play (Analytical subtype), and Medical Jeopardy (Constructive subtype).

Table 5. Survey information.

\begin{tabular}{ccl}
\hline Survey Factor & Question Number & \multicolumn{1}{c}{ Survey Statements } \\
& 1 & Active learning helped me increase my understanding of course material \\
Perceived & 2 & Active learning helped me prepare for course (Unit) Examinations \\
Individual & 4 & I learn better from lecture presentations than from active learning/small groups \\
Utility & 5 & I learned useful additional information during the active learning sessions \\
& 8 & The learning objectives helped me while reading each individual paper \\
& 13 & Group discussions allowed me to correct my mistakes to improve understanding of the concepts \\
& 6 & The active learning format was helpful in developing my information synthesizing skills \\
\hline Perceived & 7 & Solving problems in active learning sessions is an effective way to learn Biology \\
General Utility & 11 & Solving problems in a group is an effective way to practice what I have learned \\
& 12 & Application exercises (Clinical) were effective at the end of the active learning sessions \\
\hline Team & 9 & I have a positive attitude about working with my peers \\
Situation & 10 & My team worked well together \\
& 14 & There was mutual respect for other teammates' viewpoints during active learning \\
& 15 & Most students were attentive during Active learning sessions \\
\hline
\end{tabular}

* This question asks in favor of lecture learning instead of active learning. When analyzed, it was reverse scored.

Table 6. Survey statement likert scale mean scores from strongly disagree (1) to strongly agree (5).

\begin{tabular}{|c|c|c|c|c|c|c|c|c|c|c|}
\hline \multirow{2}{*}{$\begin{array}{l}\text { Question } \\
\text { Number }\end{array}$} & Fall 2012 & Fall 2013 & $\begin{array}{c}\text { Fall H } \\
2014\end{array}$ & $\begin{array}{l}\text { Spring } \\
2015\end{array}$ & $\begin{array}{c}\text { Fall H } \\
2015\end{array}$ & $\begin{array}{l}\text { Spring } \\
2016\end{array}$ & $\begin{array}{c}\text { Fall H } \\
2016\end{array}$ & $\begin{array}{c}\text { Spring } \\
2017\end{array}$ & $\begin{array}{c}\text { Fall H } \\
2017\end{array}$ & $\begin{array}{c}\text { Spring } \\
2018\end{array}$ \\
\hline & $\mathrm{n}=52 / 78$ & $\mathrm{n}=57 / 80$ & $n=25 / 28$ & $\mathrm{n}=22 / 63$ & $\mathrm{n}=20 / 24$ & $\mathrm{n}=54 / 62$ & $n=19 / 23$ & $\mathrm{n}=34 / 64$ & $n=11 / 26$ & $\mathrm{n}=30 / 60$ \\
\hline 1 & 4.06 & 4.56 & 4.60 & 4.73 & 4.75 & 4.46 & 4.79 & 4.65 & 4.82 & 4.63 \\
\hline 2 & 3.87 & 4.33 & 4.28 & 4.41 & 4.50 & 4.46 & 4.58 & 4.24 & 4.45 & 4.60 \\
\hline $3 *$ & 2.21 & 2.70 & 3.04 & 2.65 & 2.70 & 2.18 & 3.03 & 2.40 & 2.21 & 2.70 \\
\hline 4 & 4.37 & 4.56 & 4.24 & 4.41 & 4.55 & 4.46 & 4.53 & 4.38 & 4.82 & 4.43 \\
\hline 5 & 4.04 & 3.93 & 4.08 & 4.00 & 4.30 & 3.93 & 3.84 & 4.09 & 4.45 & 3.97 \\
\hline 8 & 4.25 & 4.42 & 4.60 & 4.50 & 4.65 & 4.54 & 4.58 & 4.53 & 4.73 & 4.33 \\
\hline 13 & 4.06 & 4.44 & 4.44 & 4.59 & 4.65 & 4.54 & 4.68 & 4.59 & 4.64 & 4.57 \\
\hline Factor Mean & 3.84 & 4.13 & 4.18 & 4.29 & 4.16 & 4.30 & 4.21 & 4.13 & 3.84 & 4.13 \\
\hline 6 & 4.31 & 4.54 & 4.56 & 4.59 & 4.75 & 4.48 & 4.74 & 4.50 & 4.73 & 4.40 \\
\hline 7 & 3.79 & 3.67 & 3.72 & 3.86 & 4.25 & 4.06 & 3.89 & 4.03 & 4.09 & 4.17 \\
\hline 11 & 4.48 & 4.58 & 4.72 & 4.46 & 4.85 & 4.56 & 4.63 & 4.68 & 4.91 & 4.53 \\
\hline 12 & 4.77 & 4.60 & 4.72 & 4.64 & 4.90 & 4.69 & 4.84 & 4.65 & 4.73 & 4.67 \\
\hline Factor Mean & 4.34 & 4.35 & 4.43 & 4.39 & 4.69 & 4.44 & 4.53 & 4.46 & 4.61 & 4.44 \\
\hline 9 & 4.65 & 4.72 & 4.72 & 4.55 & 4.85 & 4.78 & 4.79 & 4.74 & 4.82 & 4.67 \\
\hline 10 & 4.58 & 4.77 & 4.88 & 4.77 & 4.85 & 4.69 & 4.68 & 4.62 & 4.73 & 4.83 \\
\hline 14 & 4.67 & 4.68 & 4.88 & 4.86 & 4.85 & 4.76 & 4.95 & 4.68 & 4.91 & 4.80 \\
\hline 15 & 4.37 & 4.54 & 4.68 & 4.68 & 4.85 & 4.54 & 4.68 & 4.53 & 4.55 & 4.77 \\
\hline Factor Mean & 4.57 & 4.68 & 4.79 & 4.72 & 4.85 & 4.69 & 4.78 & 4.64 & 4.75 & 4.77 \\
\hline
\end{tabular}

Students' perception of active learning has slightly changed over six years of teaching this course. Both General Theoretical Utility and Team Situation components of the survey did not have evidence to suggest a time trend ( tau $=0.11, p$-value $=0.34$; tau $=0.13, p$-value $=0.28$ ); see Table 7 . By contrast, we found an increasing scoring trend for students' Perceived Individual Utility on active learning $($ tau $=0.21, p$-value $=0.014)$ (Table 7). This positive trend shows students' Perceived Individual Utility of active learning increased from 2012 to 2018, which suggests undergraduate biology students 
became increasingly more comfortable and satisfied with active learning in the classroom (Figure 4). The minimum survey score was a rating of 3.69 (some agreement in 2012), and the maximum score was 4.19 (moderate to strong agreement in 2016). This indicates the student perception of active learning's benefit to their learning improved from some agreement to moderate or strong agreement.

Table 7. Mann-kendall survey trend results.

\begin{tabular}{ccccc}
\hline Factor & $\mathbf{N}$ & Kendall Tau b & $p$-Value & Holm-Bonferroni Critical Value \\
\hline Perceived Individual Utility & 70 & 0.209 & $0.014^{*}$ & 0.017 \\
Perceived General Utility & 40 & 0.110 & 0.337 & 0.025 \\
Team Situation & 40 & 0.125 & 0.275 & 0.050 \\
\hline
\end{tabular}

* Significant finding.

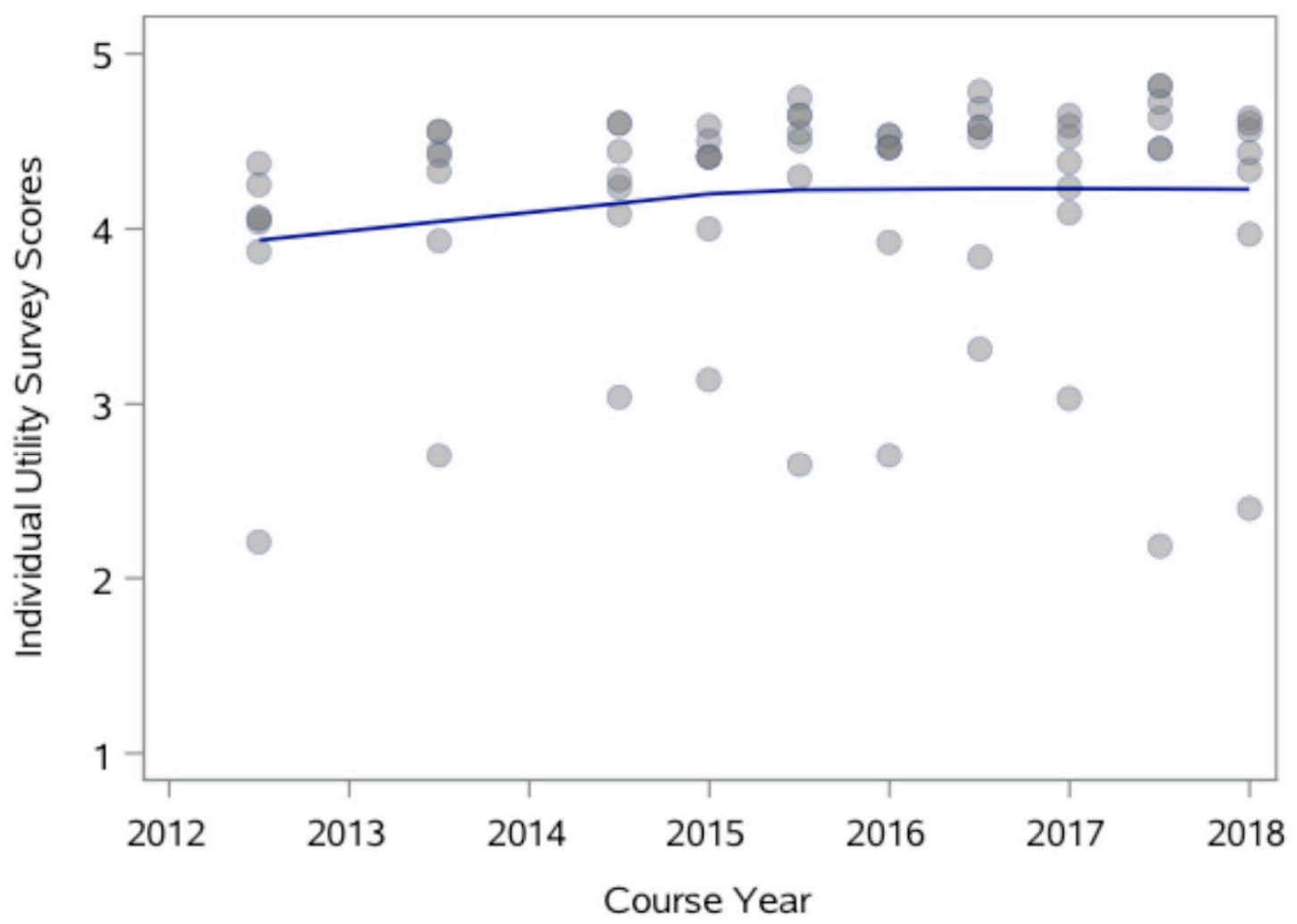

Figure 4. Scatterplot and time trend of students' Perceived Individual Utility. This plot shows the average rating (1 strongly disagree to 5 strongly agree) for each survey statement on the student's perceived Individual Utility of Active Learning across years 2012 to 2018. Spring classes are marked as whole numbers, whereas fall classes are marked as half years (2015.5). The Loess line displays the positive time trend of students' Perceived Individual Utility.

\section{Discussion}

We described five subtype categories of active learning. We used these subtype categories to compare student comprehension across the active learning methods. Our study provides evidence that teaching with distinctive active learning subtypes results in different degrees of student comprehension. We were able to determine that Recognition and Reflective active learning methods resulted in the best comprehension, which includes activities like at-home lectures and reading papers (Recognition) or at-home reading and in-class ethical discussions (Reflective). Recognition provides the ability to repeat and relearn the subject material at a students' own discretion and pace. We hypothesize that students' ability to control and tailor their learning experience allows improved subject comprehension. Reflective activities, like ethical discussions, provoke an emotional response, which may facilitate 
student comprehension of the material. Importantly, all five active learning subtypes used at-home lectures, and all subtypes demonstrated better student comprehension compared to traditional lecture learning. From this finding, we urge instructors to provide "take-home" learning options (like flipped classroom lectures) so that students can control more aspects of the course learning. We further suggest instructors use a diverse range of teaching methods to maintain student interest but be cognizant of the integrated active learning activity's efficacy (Table 8).

Table 8. Active learning topic, method description, and subtype.

\begin{tabular}{|c|c|c|}
\hline Course Topic & Active Learning Subtype & Active Learning Module Description \\
\hline \multicolumn{3}{|l|}{ Unit 1} \\
\hline Hemoglobin Structure and Function & Constructive & $\begin{array}{l}\text { A short at-home lecture followed by in-class, small group activities: } \\
\text { basic science workshop, multiple choice questions on hemoglobin } \\
\text { answered by scratch-off forms, and a short answer patient clinical case. } \\
\text { A short at-home lecture and paper to read "Mechanisms of Mammalian }\end{array}$ \\
\hline Iron-deficiency Anemia & Recognition & $\begin{array}{l}\text { Iron Homeostasis". This was followed by followed by in-class multiple } \\
\text { choice questions using scratch-off forms in small groups. } \\
\text { A short at-home lecture and paper to read, "Sickle-cell Disease". }\end{array}$ \\
\hline Sickle Cell Anemia & Analytical & $\begin{array}{l}\text { This was followed by small groups completing a clinical case study } \\
\text { medical form. }\end{array}$ \\
\hline \multicolumn{3}{|r|}{ (2) } \\
\hline Neutrophils and Acute Inflammation & Constructive & $\begin{array}{l}\text { A short at-home lecture followed by in-class, small group computer } \\
\text { based game "Corners". Each group discussed and answered } \\
\text { nine questions. }\end{array}$ \\
\hline Lymphocytes and Lymphatics & Analytical & $\begin{array}{l}\text { A short at-home lecture followed by in-class small groups researching } \\
\text { and completing three brief clinical case study medical forms. }\end{array}$ \\
\hline Monocytes & Recognition & A short at-home lecture and brief in-class review. \\
\hline Overview of Leukemia and Cancer & Analytical & $\begin{array}{l}\text { A short at-home lecture followed by in-class, small group role play. } \\
\text { Groups completed a History and Physical form and present their case to } \\
\text { the class. } \\
\text { A short at-home lecture followed by in-class, small group "Cancer }\end{array}$ \\
\hline Lymphomas & Constructive & $\begin{array}{l}\text { A short at-home lecture followed by in-class, small group "Cancer } \\
\text { Jeopardy" game. Each group discussed/responded by displaying } \\
\text { color-coded cards. }\end{array}$ \\
\hline \multicolumn{3}{|r|}{ - } \\
\hline HIV Disease / AIDS Virology & Reflective & $\begin{array}{l}\text { A short at-home lecture and review article to read, "Mechanisms of } \\
\text { Disease: Where does HIV Live?" This was followed by an in-class, } \\
\text { written thought response notecard exchange among students and short } \\
\text { class-discussion. }\end{array}$ \\
\hline HIV Disease / AIDS Therapy & Exchanging & $\begin{array}{l}\text { A short at-home lecture and PubMed biography search on HIV Disease } \\
\text { This was followed by in-class, group presentations on students' } \\
\text { findings, and ethical dilemmas were presented in class by exchanging } \\
\text { and discussing student notecard responses. }\end{array}$ \\
\hline Platelet Disorders & Analytical & $\begin{array}{l}\text { A short at-home lecture followed by in-class, small group role play. } \\
\text { Groups completed a History and Physical form and present their case to } \\
\text { the class. }\end{array}$ \\
\hline Venous Thrombosis & Recognition & $\begin{array}{l}\text { A short at-home lecture followed by an in-class short lecture and group } \\
\text { multiple choice questions answered by scratch-off forms. }\end{array}$ \\
\hline Atherosclerosis & Exchanging & $\begin{array}{l}\text { A short at-home lecture followed by student notecard exchange and } \\
\text { computer based game "Kahoot!" }\end{array}$ \\
\hline
\end{tabular}

$\mathrm{R}=$ Recognition, $\mathrm{E}=$ Exchanging, $\mathrm{C}=$ Constructive, $\mathrm{F}=$ Reflective, $\mathrm{A}=$ Analytical .

Teachers were required to adapt their course structure using an online Zoom-like format in response to the COVID-19 pandemic. F.C.C. taught and modified the course in the spring 2020 semester. Even in light of the online format, students reported enjoying active learning group sessions (personal communication, data not provided). We recommend that teachers (1) use online break-out rooms, but keep the same students in each group; (2) alternatively, the students were also asked to meet on their own time as groups using Zoom, and (3) we recommend that teachers remind the students to turn on their sound and videos in these groups. The students formed collegial bonds and re-established team-building relations during the pressing times. It was clear that most of the students reacted positively to re-joining their groups. Furthermore, as mentioned earlier, Recognition (such as at-home lectures and reading papers) was the most beneficial to students' comprehension. We believe this insight could encourage and normalize at-home learning and working opportunities for students and the workforce. While the COVID-19 pandemic was not directly studied and has its own challenges, take-home options allow people to control and customize their working and learning environment.

We then estimated and compared student comprehension of active learning topics and didactic lecturing topics within a course. We provide evidence that active learning improves course material 
comprehension on later exams. This study estimates a student will score better on future exams taught with active learning techniques compared to material taught through lecturing on average. The bivariate random intercept method captures the dependencies between repeated observations and decomposes the exam variability into student-level and observation-level variance. Therefore, we have evidence to believe that within a student course, material comprehension improves with active learning methods. Using the same professor to teach both groups (active learning and traditional lecture formats) removed the teacher as an additional variable in this comparison [41,42].

Both the honors and non-honors sections contain high-performing senior undergraduates, and the results may be different if the course contained less-experienced undergraduate students. We would like to emphasize that the value of active learning extends beyond exam comprehension, which was analyzed here. Active learning provides diversity in students' learning experience and acceptance of students from varying backgrounds. Many undergraduate students are pursuing science-related majors that will ultimately lead to careers in a variety of professional health fields, public service, education, or in basic/applied/pharmaceutical/government research. Active learning emphasizes team-based skills, which are essential skills to possess to successfully navigate in any of the aforementioned fields.

We provide evidence that student comprehension within a course varies between active learning and lecture learning, but our reported difference, $0.66-1.57 \%$ mean improvement, is smaller than previously reported improvement. STEM courses comparing active and lecture teaching methods show an average $6 \%$ in improvement, which compares comprehension across entire courses [43,44]. Our reported result is clinically small yet statistically significant, and we hypothesize that a different, interacting relationship may exist. Does an instructor who uses active learning not only improve comprehension on the material taught with active learning but also improve comprehension on material taught through lecture learning?

If this relationship exists, this suggests students' overall exam score will improve with blended teaching methods (both active and lecture learning methods). Therefore, the observable difference between lecture learning comprehension and active learning comprehension will decrease in blended learning environments; however, the overall comprehension will be improved. This interacting relationship will be critical to fully understand student learning when active learning methods are merged with lecture learning in the same course.

We present findings from a 15-statement survey on active learning given to students, which shows an increasing trend in student acceptance of active learning methods in the classroom. The survey data exposes an important aspect of students' self-reported learning experience. Students in this biology course tend to enjoy the diversity in teaching styles, respond positively to active learning, and are satisfied to very satisfied with active learning. Our results show an increasing trend for students' Perceived Individual Utility of active learning over the years 2012 to 2018 . The cause of this trend is undeterminable and could be attributed to many interacting scenarios, such as the increased student familiarity with active learning or improved teaching by the professor. These results are beneficial to instructors because not only are students learning better with active learning, but students' perceptions of active learning are positively shifting to encourage its use in the classroom.

The limitations of this paper include the inability to control for age, gender, ethnicity, and other potential extraneous variables in analyses, which may confound results in this observational setting. We did not have demographic information; however, we believe using data to the best of their ability is a strength in this study. Thus, even if we could get information about a student's gender, age, etc., from the registrar's office, they would be "aggregate" variables (i.e., 49\% female). Aggregate variables, like census-derived variables, hold limited information and are typically removed in statistical analyses. Additionally, our analysis looks at comprehension based on exam performance, but does not look at long-term comprehension, which is known to vary based on the original teaching method [45]. The students were typically high-performing and upper-level biology majors at UNC-CH, and our results may only be applicable to a similar classroom composition. Another limitation is the clustering of exam scores, making differences small, which may be due to excluding essay-type exam questions in 
analyses. Biology-based Teaching Assistants to help manage the course were not available to make this possible. Importantly, our results agree with previous reports describing an increase in comprehension comparing active learning to lecture learning, but our results evaluate the improvement within a course using both lecture and active learning methods.

\section{Conclusions}

The traditional method for teaching science courses at the University level is through lecturing where students are passively listening to the instructor [19]. By contrast, active learning methods are engaging to students and emphasize that learners have an integral role in in their own learning [19]. We know from the foundational studies of Bloom and associates and the many stellar educators who have modified Bloom's Taxonomy of Learning, that learning is a complex process [29-33] and that students learn, store, process, and recall information differently in an individual manner [24]. Our study was focused on the description and use of active learning subtypes to complement this complex, individual learning process. Figure 5 shows an overview of the five active learning subtypes next to the description of the six aspects of learning in Bloom's Revised Taxonomy, which provided the groundwork and model for this research.

\section{Active Learning Subtypes}

\begin{tabular}{|c|c|c|c|c|}
\hline RECOGNITION & EXCHANGING & REFLECTIVE & CONSTRUCTIVE & ANALYTICAL \\
\hline $\begin{array}{l}\text { Independent } \\
\text { student thinking } \\
\text { and some, but } \\
\text { minor, group } \\
\text { communication. }\end{array}$ & $\begin{array}{l}\text { Independent } \\
\text { student thinking } \\
\text { combined with } \\
\text { group communi- } \\
\text { cation and } \\
\text { exchanging } \\
\text { thoughts. }\end{array}$ & $\begin{array}{l}\text { Combines an } \\
\text { academic and } \\
\text { personal compo- } \\
\text { nent to enrich } \\
\text { student under- } \\
\text { standing and } \\
\text { learning. }\end{array}$ & $\begin{array}{l}\text { Group discussion } \\
\text { of class material } \\
\text { to work and learn } \\
\text { together, and to } \\
\text { synthesize an } \\
\text { answer. }\end{array}$ & $\begin{array}{l}\text { Requires applica- } \\
\text { tion of knowledge } \\
\text { and deep critical } \\
\text { thinking along with } \\
\text { group collaboration } \\
\text { and discussion. }\end{array}$ \\
\hline
\end{tabular}

\section{Bloom's Revised Taxonomy}

\begin{tabular}{|c|c|c|c|c|}
\hline $\begin{array}{c}\text { REMEMBER/ } \\
\text { UNDERSTAND }\end{array}$ & \multirow{2}{*}{$\begin{array}{l}\text { APPLY } \\
\text { Be able to apply } \\
\text { knowledge in new } \\
\text { situations, to begin } \\
\text { to solve problems, } \\
\text { and to think and } \\
\text { answer questions. }\end{array}$} & \multirow{2}{*}{$\begin{array}{l}\text { ANALYZE } \\
\text { Be able to explain } \\
\text { the relationships } \\
\text { of the knowledge } \\
\text { you are learning, } \\
\text { and to use this } \\
\text { information in } \\
\text { new situations. }\end{array}$} & \multirow{2}{*}{$\begin{array}{l}\text { EVALUATE } \\
\text { Be able to judge } \\
\text { a situation and } \\
\text { be able to } \\
\text { express/describe } \\
\text { the value of the } \\
\text { presented } \\
\text { material. }\end{array}$} & \multirow{2}{*}{$\begin{array}{l}\text { CREATE } \\
\text { Be able to produce } \\
\text { something new, by } \\
\text { bringing together } \\
\text { parts of knowledge } \\
\text { to synthesize } \\
\text { information on your } \\
\text { own. }\end{array}$} \\
\hline $\begin{array}{l}\text { Be able to recall } \\
\text { information, dates, } \\
\text { formulas and } \\
\text { theories; and be } \\
\text { able to express it in } \\
\text { your own words. }\end{array}$ & & & & \\
\hline
\end{tabular}

Figure 5. Overview of the five active learning subtypes compared to the six components of Bloom's Revised Taxonomy of Learning (adapted from [29]).

Our results imply that the use of active learning subtypes strengthens the educational value of active learning methods for new course development and assessment. Further research is needed to complete an understanding of active learning and its benefits regarding comprehension, especially long-term knowledge, the difference between honors and non-honors sections, and the potential interacting relationship using both active and lecture learning methods in a blended teaching style. Finally, we hope the positive trend in student acceptance of active learning will improve further and that researchers continue to evaluate students' perceptions on active learning as it becomes more integrated into students' educational experience.

Author Contributions: Conceptualization, F.C.C. and K.M.M.; methodology, K.M.M. and F.C.C.; software, K.M.M.; formal analysis, K.M.M.; resources, F.C.C.; data curation, K.M.M. and F.C.C.; writing-original draft preparation, K.M.M. and F.C.C.; writing-review and editing, K.M.M. and F.C.C.; visualization, K.M.M. and F.C.C.; project administration, F.C.C. Both authors agreed to the published version of the manuscript. All authors have read and agreed to the published version of the manuscript.

Funding: This research received no external funding. 
Acknowledgments: We are most grateful to all of the students of "Biology of Blood Diseases"; it has been an honor teaching you and to allow F.C.C. the opportunity to develop and implement the active learning methods described here. We thank Kathryn W. Smith for bringing all of the "games" (Kahoot! Plickers, Jeopardy, Quizizz, etc.) to our attention because they continue to work well and the students are very receptive to them. We acknowledge Gary L. Beck Dallaghan, Kurt Gilliland, Johanna Foster, Jana Nietmann, and Kathryn W. Smith for their useful suggestions in preparing the manuscript. F.C.C. gratefully acknowledges Russell R. Broaddus, Joe W. and Evelyn M. Grisham Distinguished Professor and Department Chair, in the Department of Pathology and Laboratory Medicine at UNC School of Medicine, for continued support of his education research/scholarship.

Conflicts of Interest: The authors declare no conflict of interest.

\section{References}

1. Cohn, D.; Atlas, L.; Ladner, R. Improving generalization with active learning. Mach. Learn. 1994, 15, $201-221$. [CrossRef]

2. Auerbach, A.; Higgins, M.; Brickman, P.; Andrews, T. Teacher knowledge for active-learning instruction: Expert-novice comparison reveals differences. CBE Life Sci. Educ. 2018, 17, ar12. [CrossRef]

3. Grabinger, R.S.; Dunlap, J.C. Rich environments for active learning: A definition. Assoc. Learn. Technol. J. 1995, 3, 5-34. [CrossRef]

4. Johnson, D.W.; Johnson, R.T.; Smith, K.A. Active learning: Cooperation in the college classroom. Ann. Rep. Educ. Psychol. Jpn. 2008, 47, 29-30. [CrossRef]

5. Bonwell, C.C.; Eison, J.A. Active Learning: Creating Excitement in the Classroom: 1991 ASHE-ERIC Higher Education Reports; The George Washington University: Washington, DC, USA, 1991.

6. Phillips, J.M. Strategies for active learning in online continuing education. J. Contin. Educ. Nurs. 2005, 36, 77-83. [CrossRef]

7. Prince, M. Does active learning work? A review of the research. J. Eng. Educ. 2004, 93, 223-231.

8. Roehl, A.; Reddy, S.L.; Shannon, G.J. The flipped classroom: An opportunity to engage millennial students through active learning strategies. J. Fam. Consum. Sci. 2013, 105, 44-49. [CrossRef]

9. Rowles, C.J.; Brigham, C. Strategies to promote critical thinking and active learning. In Teaching in Nursing: A Guide for Faculty; Saunders: Amsterdam, The Netherlands, 2005; Volume 2, pp. 283-315.

10. Schon, D.A. Educating the reflective practitioner: Toward a new design for teaching and learning in the professions. Aust. J. Adult Learn. 2010, 50, 448-451.

11. Walker, S.E. Active learning strategies to promote critical thinking. J. Athl. Train. 2003, 38, 263. [PubMed]

12. Weinstein, C.E.; Underwood, V.L. Learning strategies: The how of learning. Think. Learn. Skills 1985, 1, 241-258.

13. Youngblood, N.; Beitz, J.M. Developing critical thinking with active learning strategies. Nurse Educ. 2001, 26, 39-42. [CrossRef]

14. Braxton, J.M.; Milem, J.F.; Sullivan, A.S. The influence of active learning on the college student departure process: Toward a revision of Tinto's theory. J. High. Educ. 2000, 71, 569-590. [CrossRef]

15. Chickering, A.W.; Gamson, Z.F. Seven principles for good practice in undergraduate education. AAHE Bull. $1987,3,7$.

16. Georgiou, H.; Sharma, M. Does using active learning in thermodynamics lectures improve students' conceptual understanding and learning experiences? Eur. J. Phys. 2014, 36, 15020. [CrossRef]

17. Blasco-Arcas, L.; Buil, I.; Hernández-Ortega, B.; Sese, F.J. Using clickers in class: The role of interactivity, active collaborative learning and engagement in learning performance. Comput. Educ. 2013, 62, 102-110. [CrossRef]

18. Carr, R.; Palmer, S.; Hagel, P. Active learning: The importance of developing a comprehensive measure. Act. Learn. High. Educ. 2015, 16, 173-186. [CrossRef]

19. Stains, M.; Harshman, J.; Barker, M.K.; Chasteen, S.V.; Cole, R.; DeChenne-Peters, S.E.; Eagan, M.; Esson, J.M.; Knight, J.K.; Laski, F.A. Anatomy of STEM teaching in North American universities. Science 2018, 359, 1468-1470. [CrossRef]

20. Santos, J.; Figueiredo, A.S.; Vieira, M. Innovative pedagogical practices in higher education: An integrative literature review. Nurse Educ. Today 2019, 72, 12-17. [CrossRef]

21. Evans, L.; Bosch, M.L.V.; Harrington, S.; Schoofs, N.; Coviak, C. Flipping the classroom in health care higher education: A systematic review. Nurse Educ. 2019, 44, 74-78. [CrossRef] 
22. Johnson, K.M. Implementing Inclusive Practices in an Active Learning STEM Classroom; American Physiological Society: Bethesda, MD, USA, 2019.

23. Knudson, D. Active learning and student beliefs about learning. ISBS Proc. Arch. 2019, 37, 328.

24. Tanner, K.; Allen, D. Approaches to biology teaching and learning: Learning styles and the problem of instructional selection-Engaging all students in science courses. Cell Biol. Educ. 2004, 3, 197-201. [CrossRef] [PubMed]

25. Michael, J. Where's the evidence that active learning works? Adv. Physiol. Educ. 2006, 30, 159-167. [CrossRef] [PubMed]

26. Gopalan, C. The use of innovative active learning strategies on student learning outcomes. MOJ Anat. Physiol. 2016, 2, 41. [CrossRef]

27. Ramirez-Loaiza, M.E.; Sharma, M.; Kumar, G.; Bilgic, M. Active learning: An empirical study of common baselines. Data Min. Knowl. Discov. 2017, 31, 287-313. [CrossRef]

28. Journey with Parkinson's. Available online: https://journeywithparkinsons.com/ (accessed on 1 July 2020).

29. Anderson, L.W.; Krathwohl, D.R. A Taxonomy for Learning, Teaching and Assessing: A Revision of Bloom's Taxonomy of Educational Objectives; Longman: New York, NY, USA, 2001.

30. Bloom, B.S. Bloom's Taxonomy; David McKay: New York, NY, USA, 1956.

31. Conklin, J. A Taxonomy for Learning, Teaching, and Assessing: A Revision of Bloom's Taxonomy of Educational Objectives Complete Edition; JSTOR: New York, NY, USA, 2005.

32. Fink, L.D. The power of course design to increase student engagement and learning. Peer Rev. 2007, 9, 13-17.

33. Fink, L.D. Creating Significant Learning Experiences: An Integrated Approach to Designing College Courses; John Wiley and Sons: Hoboken, NJ, USA, 2013.

34. Chi, M.T.; Wylie, R. The ICAP framework: Linking cognitive engagement to active learning outcomes. Educ. Psychol. 2014, 49, 219-243. [CrossRef]

35. Kruskal, W.H.; Wallis, W.A. Use of ranks in one-criterion variance analysis. J. Am. Stat. Assoc. 1952, 47, 583-621. [CrossRef]

36. Critchlow, D.E.; Fligner, M.A. On distribution-free multiple comparisons in the one-way analysis of variance. Commun. Stat. Theory Methods 1991, 20, 127-139.

37. Vasan, N.S.; DeFouw, D.O.; Compton, S. A survey of student perceptions of team-based learning in anatomy curriculum: Favorable views unrelated to grades. Anat. Sci. Educ. 2009, 2, 150-155. [CrossRef]

38. Kendall, M.G. Rank Correlation Methods; Hafner Publishing Co.: New York, NY, USA, 1955.

39. Holm, S. A simple sequentially rejective multiple test procedure. Scand. J. Stat. 1979, 65-70. [CrossRef]

40. Wilcoxon, F. Individual comparisons by ranking methods. Biom. Bull. 1945, 1, 80-83. [CrossRef]

41. Mierdel, J.; Bogner, F.X. Comparing the use of two different model approaches on students' understanding of DNA models. Educ. Sci. 2019, 9, 115. [CrossRef]

42. Randler, C.; Bogner, F.X. Planning experiments in science education research: Comparison of a quasi-experimental approach with a matched pair tandem design. Int. J. Environ. Sci. Educ. 2008, 3, 95-103.

43. Freeman, S.; Eddy, S.L.; McDonough, M.; Smith, M.K.; Okoroafor, N.; Jordt, H.; Wenderoth, M.P. Active learning increases student performance in science, engineering, and mathematics. Proc. Natl. Acad. Sci. USA 2014, 111, 8410-8415. [CrossRef]

44. Springer, L.; Stanne, M.E.; Donovan, S.S. Effects of small-group learning on undergraduates in science, mathematics, engineering, and technology: A meta-analysis. Rev. Educ. Res. 1999, 69, 21-51. [CrossRef]

45. Jensen, J.L.; Kummer, T.A.; Godoy, P.D.D.M. Improvements from a flipped classroom may simply be the fruits of active learning. CBE Life Sci. Educ. 2015, 14, ar5. [CrossRef]

(C) 2020 by the authors. Licensee MDPI, Basel, Switzerland. This article is an open access article distributed under the terms and conditions of the Creative Commons Attribution (CC BY) license (http://creativecommons.org/licenses/by/4.0/). 